\title{
$\begin{array}{lllllllll}S & \mathrm{Y} & \mathrm{M} & \mathrm{P} & \mathrm{O} & \mathrm{S} & \mathrm{I} & \mathrm{U} & \mathrm{M}\end{array}$
}

\section{INSTITUTIONS, ENTREPRENEURSHIP, AND ECONOMIC GROWTH: WHAT DO WE KNOW AND WHAT DO WE STILL NEED TO KNOW?}

\author{
CHRISTIAN BJØRNSKOV \\ Aarhus University \\ NICOLAI J. FOSS \\ Bocconi University
}

\begin{abstract}
We review the literature that links institutions, entrepreneurship, and economic growth outcomes, focusing in particular on empirical research. Most of the literature has an economics orientation, but we also review relevant literature from other social sciences, including management research. The review helps identify a number of conceptual, theoretical, and empirical gaps, calling for further research. For example, the literature narrowly identifies entrepreneurship with start-ups and self-employment; does not theorize many potentially relevant inter-level links and mechanisms; and suffers from sample limitations, omitted variable biases, causality issues, and response heterogeneity. We argue that theories in management research, such as the resource-based view, transaction cost economics, and strategic entrepreneurship theory, can fill some of the conceptual and theoretical gaps.
\end{abstract}

Much of the recent social science interest in entrepreneurship, including management research, is arguably derived from the importance of entrepreneurship outcomes at higher levels-that is, resource allocation, economic growth, and social change more generally. "The entrepreneur," declared Israel Kirzner (1980, p. 5), "is the prime mover of progress." "Progress" here means industry dynamism, start-up activity, corporate renewal, and the creation and renewal of competitive advantages, as well as technological progress and economic growth. Because of the obvious importance of such progress, understanding the multilevel antecedents of entrepreneurship and how the entrepreneurship of firms and individuals aggregates up to economy-wide consequences should be of very high importance to social scientists (cf. Shepherd, 2011). And yet, there is surprisingly little work that systematically links the antecedents of entrepreneurship, entrepreneurial activity itself, and the aggregate consequences thereof in a unified framework (Bjørnskov \& Foss, 2008, 2013; Holcombe, 1998). The reason is that multilevel inquiry into the causes and consequences of entrepreneurial decisions and actions is a highly complex undertaking that has been hampered by the absence of unified theorizing and useful data sources.

Economics interest in entrepreneurship as a cause of growth is rather recent; not much work exists on the subject, and most of it is theoretical (e.g., Aghion \& Howitt, 1992; Baumol, 1990; Blanchflower, 2000; Blau, 1987; Parker, 2005; Wennekers \& Thurik, 1999). Interest in entrepreneurship in the other social sciences, such as sociology (Thornton, 1999), anthropology (Oxfeld, 1992), political science (Klein, Mahoney, McGahan, \& Pitelis, 2010), and economic and business history (Landes, Mokyr, \& Baumol, 2010), is also a relatively recent phenomenon. In any case, specific interest in the institutions-entrepreneurship-aggregate performance nexus is largely confined to economics. Therefore, our review and discussion mainly relates to economics, although we also discuss the potential of sociology to expand our understanding of the consequences of institutions on entrepreneurship, and the ability of management research to deal with the micro-mechanisms of entrepreneurship. 
Specifically, we first review most of the extant empirical research that deals with the institutional drivers and the aggregate consequences of entrepreneurship. We identify several closely related conceptual, theoretical, and empirical gaps in this literature and discuss how these gaps may be filled. Some of the gaps have to do with conceptualizing (and, in turn, operationalizing and measuring) the key variables. For example, most of the literature in economics and sociology takes entrepreneurship to be exclusively about start-ups and/or self-employment (Foss \& Klein, 2012; Foss \& Lyngsie, 2012; Parker, 2005, 2011). However, management research points to entrepreneurship by established firms as a very real factor of substantive importance. As another example, most work on the impact of institutions on entrepreneurs takes an economics perspective on the relationship between entrepreneurship and institutions. While economists traditionally emphasize relatively "hard" economic constraints implied by institutions, such as the stability and enforceability of property rights and non-confiscatory tax regimes and regulations (e.g., North, 1990), sociologists may put more emphasis on "soft" aspects, such as shared values and cognition (Scott, 1995), that are embodied in institutions and may also matter to entrepreneurship. ${ }^{1}$

We also point to several gaps in the understanding of the mechanisms that link institutions, entrepreneurship, and growth, or, in sociology parlance, the structure-agency relation(s). Thus, our literature review reveals that most studies tend to overlook many theoretically relevant ways in which firms and entrepreneurs mediate the relationship between institutions/policies and aggregate outcomes. Empirically, the reviewed literature suffers from sample limitations, omitted variable biases, causality issues, and response heterogeneity. Some of the latter problems turn on statistical issues that are independent of conceptual and theoretical considerations. However, some are heavily dependent on, for example, how

\footnotetext{
${ }^{1}$ Scott (1995) broadened the entrepreneurship concept to include institutional entrepreneurship, commonly described as "activities of actors who have an interest in particular institutional arrangements and who leverage resources to create new institutions or to transform existing ones" (Garud, Hardy, \& Maguire, 2007, p. 958). While the topic of institutional entrepreneurship is of clear interest, it is also quite close to the concepts of political rent-seeking, as analyzed in public choice and political economy (cf. Munger, 2008), and Baumol's (1990) concept of destructive entrepreneurship.
}

entrepreneurship is conceptualized or how the "transmission mechanism" from institutions/policies to aggregate outcomes in terms of economic performance is theorized.

Filling such gaps calls for drawing on prominent theories in management research, such as the resourcebased view, strategic entrepreneurship theory, and work on institutional entrepreneurship (Pacheco, York, Dean, \& Sarasvathy, 2010), as well as, for example, transaction cost economics (Williamson, 1996), new institutional economics (North, 1990), and institutionalism in sociology (Scott, 1995). We offer a sketch of what such multilevel/multifield theorizing may look like. The specific argument we outline is that institutions and policies at the level of the regional or national economy influence the aggregate elasticity of substitution, an important mechanism in the growth process, which may be loosely defined as the flexibility with which resources can be combined. Institutions and policies exert this influence because they influence the (transaction) costs of entrepreneurs searching for, combining, and adapting heterogeneous resources in the pursuit of profit under uncertainty. Entrepreneurial activity depends systematically on such costs, and hence the impact of entrepreneurship on aggregate economic performance, notably growth, is thus dependent on the transaction costs of resource assembly and their antecedents. In sum, key ideas in management research can help us understand the economic mechanisms that mediate the institutional influence on aggregate economic performance.

\section{BACKGROUND AND LITERATURE REVIEW}

\section{Background: The Entrepreneur in the Social Sciences}

The social science concern with the entrepreneurial function predates even Adam Smith's Wealth of Nations, often taken to be the birth certificate of economics: Richard Cantillon's Essai sur la Nature du Commerce en Général was published 21 years prior to Smith's classic. Economists, in particular, have contributed to conceptualizing the entrepreneur and defining a role for the entrepreneurial function in the broader economic system (Baumol, 1990, 1993; Kirzner, 1980, 1997; Knight, 1921; von Mises, 1949; Schumpeter, 1911). Other social scientists as well as management scholars contributed much later to the entrepreneurship field.

However, in spite of originating the social science inquiry into the entrepreneur, the economics and 
management research literatures have until recently been almost silent on the institutional and policy antecedents of the incidence and nature (i.e., whether productive or destructive) of entrepreneurship (Baumol, 1990; Foss \& Klein, 2012; Zahra \& Wright, 2011). For example, Bjørnskov and Foss (2008) pointed out that the classical writers on entrepreneurship in economics-notably, Schumpeter (1911), Knight (1921), von Mises (1949), Kirzner (1973), and Casson (1982) — discussed the antecedents of entrepreneurship rather sparsely, concentrating on personal characteristics or simply the lure of profit. $^{2}$ The main reason is arguably that the classical entrepreneurship scholars-who were virtually all economists-were taken up with defining the entrepreneurship construct and its role in economic theory. This has not always been appreciated in management research. Thus, Foss and Klein (2012, in press) pointed to the irony in the fact that although the work of Kirzner $(1973,1997)$ is heavily cited in recent management research on entrepreneurship, and ostensibly supplies key insights for an important contemporary approach to entrepreneurship in management (Shane, 2000), he deliberately does not offer any psychological or other detail on the entrepreneur. Instead, Kirzner's interest is almost solely in the consequences of entrepreneurship-the process of market equilibration. Since disequilibrium means that unexploited profit opportunities exist, positing the existence of a particular human faculty (albeit one that may be asymmetrically distributed)—namely, the "alertness" to hitherto unrecognized opportunities for profitprovides the basis for a theory of equilibration.

\section{Some Recent Economics Work on Entrepreneurship}

Kirzner and the rest of the classical entrepreneurship scholars concentrate on the functions of entrepreneurship (Klein, 2008), whether equilibrating (Kirzner, 1973), disrupting (Schumpeter, 1911), or creating (Casson, 1982) markets or forming new firms (Knight, 1921). Klein (2008) contrasted this with the tendency in recent labor economics and the economics of entrepreneurship to conceptualize entrepreneurship as an occupational choice-that is, a choice between being an employee and being selfemployed (Kihlström \& Laffont, 1979; Lucas, 1978;

\footnotetext{
${ }^{2}$ Schumpeter (1911) does point to technology and finance as antecedents, and von Mises (1949) discusses the role of regulation as a factor that hampers the exercise of the entrepreneurial function.
}

Parker, 2005). ${ }^{3}$ Both views, however, imply that there are aggregate consequences of entrepreneurs starting firms to help them realize the opportunities they perceive (Holmes \& Schmitz, 1990), and that in doing this entrepreneurs appear as "portfolio" or "serial" entrepreneurs (Parker, 2005; Westhead \& Wright, 1998). And yet, it is only rather recently that economists have begun to systematically model and measure the economy-level consequences of entrepreneurship (cf. Bjørnskov \& Foss, 2013), beginning with Baumol (1990, 1993), Schmitz (1989), and Aghion and Howitt (1992). Baumol (1990) basically assumed that the supply of entrepreneurship in an economy is a constant, but then argued that outcomes may differ dramatically depending on which kind of entrepreneurial activity-productive, unproductive, or destructive-the institutional matrix incentivizes. In Baumol's conceptualization of the role of entrepreneurs, institutions and policies thus affect the productivity of entrepreneurial activity instead of the supply of it.

Schmitz (1989) and Aghion and Howitt (1992) built on Schumpeterian foundations and in different ways endogenized entrepreneurial activity, which then aggregates up to economy-wide growth. Entrepreneurship has also been included in models that are based on the so-called "endogenous" or "new" growth theory (e.g., Erken et al., 2008; Romer, 1990). In general, economists have increasingly modeled entrepreneurship as the mechanism that picks and implements process innovations (that improve productivity) and product innovations (that expand choice options) that may drive growth (e.g., Acs, Braunerhjelm, Audretsch, \& Carlsson, 2009; Agarwal, Audretsch, \& Sarkar, 2010; Aghion \& Howitt, 1998a; Wennekers \& Thurik, 1999). For example, akin to Schumpeter (1911), Audretsch et al. (2006) and Acs et al. (2004) suggested that entrepreneurs search within the available knowledge stock and pick "knowledge bits" that may give rise to new products or processes. This conceptualization links directly to

\footnotetext{
${ }^{3}$ The occupational choice conceptualization of entrepreneurship associates it strictly with self-employment and the formation of new firms. Given the importance of start-ups for the overall dynamism of the economy (Storey, 1994), this is a conceptualization that makes sense. However, it neglects wider views of entrepreneurship, such as the view that it is a type of behavior that can also be exercised by established firms (Foss \& Lyngsie, 2014).

${ }^{4}$ Still, "entrepreneur" does not appear in the index of Aghion and Howitt's (1998b) magisterial textbook on endogenous growth theory.
} 
institutional and policy concerns, as it supplies a rationale for public R\&D policies (see also Zahra \& Wright, 2011).

In all, however, it would be an exaggeration to say that entrepreneurship features prominently in the literature on the economics of growth. For example, Temple's (1999) overview of empirical work on growth does not mention entrepreneurship at all. A number of more recent publications do in fact empirically link entrepreneurship and growth (e.g., Audretsch, Keilbach, \& Lehmann, 2006; van Stel, 2006), but it remains fair to say that, first, such recent work is not part of mainstream growth economics, and second, this mainstream still-even in spite of Aghion and Howitt's (1992) work-remains relatively uninterested in exploring the role of entrepreneurship in the growth process. ${ }^{5}$ Thus, interest in mainstream economics in linking growth and entrepreneurship seems to be located either in a very specific, mainly formal, approach that is based on Aghion and Howitt (1992, 1998a) and Aghion, Akcigit, and Howitt (2014), in Baumol's work (1990, 1993), or in more popular writing (e.g., Baumol, Litan, \& Schramm, 2007).

\section{The Entrepreneurship Research Gap: Lack of Data and Constraining Assumptions}

There are many reasons for the relative lack of systematic inquiry into the (multilevel) antecedents and consequences of entrepreneurship in social science and management research. The first is a basic issue of data availability: Successfully conducting multilevel quantitative empirics requires quality data that allow for sufficient variation at the relevant levels. Such data have only very recently been made available: The first dataset (the Global Entrepreneurship Monitor dataset) that allows for such comparisons was first made available as late as 1999 . Data that allow for measuring institutional and economic policy go somewhat further back in time; serious empirical cross-country work that links economic growth to such data can be dated to Barro (1991).

The second reason is that most social science for a long time simply took little interest in the

\footnotetext{
${ }^{5}$ In the most recent Handbook of Economic Growth (Aghion \& Durlauf, 2015), unlike previous handbooks, entrepreneurship is covered in two chapters. However, both chapters develop formal mathematical growth models on Schumpeterian foundations. These models and the antecedent chapters in the handbook are conceptually entirely unconnected to the chapters on institutions.
}

entrepreneur. Beginning with Hayek (1945) and von Mises (1949), many have argued that the advent and dominance of the formal/mathematical mode of discourse in economics, with its attendant assumptions about information and equilibrium that became dominant after World War II, meant that the entrepreneur got squeezed out of economics entirely (e.g., Bianchi \& Henrekson, 2005; Kirzner, 1973). The argument is that the use of functional forms, mathematical constants, full information assumptions, and equilibrium reasoning leaves little room for creative entrepreneurial acts that transcend given meansends frameworks and exploit pockets of ignorance in the market (Cosgel, 1996; Kirzner, 1973, 1997). However, the problem is not mathematization/ formalization as such-a number of formal models of the entrepreneurial function and its market-level outcomes indeed exist (e.g., Kaul, 2013; Littlechild \& Owen, 1980; Yates, 2000)—but rather the assumptions about information and/or risk and uncertainty that are fed into formal economics models. In particular, Knightian uncertainty-situations central to entrepreneurial activity where agents make decisions based on an unknown distribution of the outcomes (Foss \& Klein, 2012)—is very difficult to incorporate into the type of formal mathematical modeling that is central to modern growth theory.

Other social sciences, such as sociology and political science, have traditionally taken even less interest than economics in the entrepreneur. ${ }^{6}$ However, within the past decade or so, scholars working from a sociology perspective have increasingly taken an interest in the entrepreneur and the consequences of entrepreneurship, as witnessed by recent work that has built on the concept of "institutional entrepreneurship" (DiMaggio, 1988; cf. Pacheco et al., 2010). This literature focuses on how actors can deploy resources, investments, and actions to deliberately create or change institutional arrangements in such a way that their interests are furthered, for example, by engaging in creative ways of rent-seeking (e.g., lobbying) relative to political decision makers. As such, it is closely related to the concepts of rentseeking and lobbyism as analyzed in public choice and political economy for half a century (cf. Baumol, 1990; Munger, 2008; Henrekson \& Sanandaji, 2010).

Of course, management research has been explicitly concerned with entrepreneurship for more than several decades. Yet for a long time the study of

\footnotetext{
${ }^{6}$ The work of Howard Aldrich stands out as an exception; see Aldrich (2011) for a collection of his sociology on entrepreneurship over several decades.
} 
entrepreneurship remained synonymous with the study of small firms and even family firms (Foss \& Klein, 2012), and the idea of the study of entrepreneurship as sui generis arguably did not gain widespread acceptance until the 1980s (e.g., the Journal of Business Venturing was founded in 1985). Clearly articulated research programs have appeared rather recently. The opportunity discovery stream of research associated most directly with Scott Shane (Shane, 2000; Shane \& Venkataraman, 2000) represents perhaps the first major distinct program in management entrepreneurship research. To date, most management entrepreneurship research has also been largely micro in the sense that macro antecedents and outcomes of entrepreneurship have not been examined. ${ }^{7}$

\section{Institutions, Entrepreneurship, and Economic Outcomes: Levels and Links}

In spite of the above challenges related to data availability and theoretical assumptions, a small literature has begun to explore the links between institutions and economic policy (antecedents), entrepreneurship, and aggregate outcomes, notably economic growth. To get a basic grip on those links, consider the so-called "Coleman bathtub" (Coleman, 1990) depicted in Figure 1. This will also serve as a diagnostic tool that will help us identify a number of key gaps in the extant literature.

The diagram is a basic two-level (micro-macro) structure that depicts inter-level relations as causal, and asserts that all macro-to-macro links are in actuality mediated by links that involve the micro level (the underlying argument is that no causal mechanisms unfold entirely on the macro level). Thus, there is a causal link from the matrix of incentives represented by institutions and economic policies represented by the node in the upper left corner of the diagram (macro) to the conditions of entrepreneurship, represented by the lower left node (micro). Such conditions include typical economic constraints and enablers, such as prices and personal wealth (Henrekson, 2005), that directly influence entrepreneurial decision making (i.e., arrow 2 in Figure 1).

\footnotetext{
${ }^{7}$ This depends somewhat on where one locates "macro." If networks, organizational structures, etc., are seen as "macro," then a considerable amount of work has been done on this. However, if "macro" is considered the national or state level (as in this paper), the claim holds true.
}

FIGURE 1

\section{Illustrating Links Between Institutions/Policies, Entrepreneurship, and Outcomes}

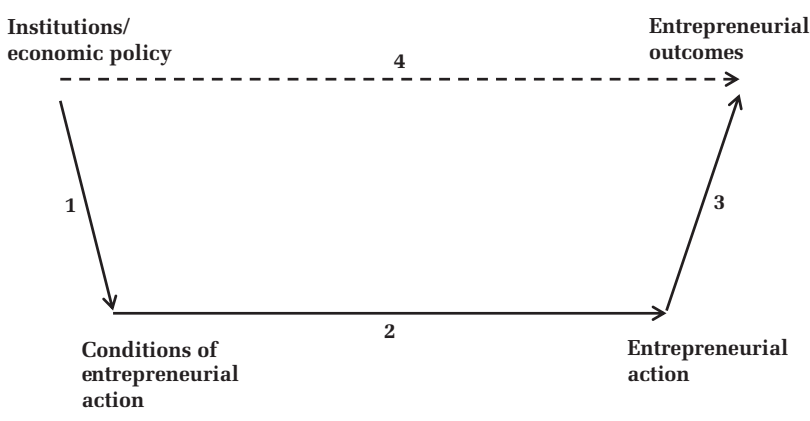

However, as sociological institutionalism suggests, institutions are not just more or less explicitly designed external constraints on actions, as in North's (1990, p. 3) definition of institutions as the "humanly devised constraints" on action. Institutions are also emergent (Hayek, 1973). They transmit values and influence cognition by providing shared cognitive categories (e.g., how risk is perceived and evaluated) and norms (e.g., how acceptable it is to break norms, be competitive, etc.) that are internalized by actors (Denzau \& North, 1994; Scott, 1995) and that may influence the conditions of entrepreneurial action, as the actors see these (Pacheco et al., 2010). ${ }^{8}$ As Shepherd (2011) suggested, a possible bridge between the institutional and the individual level (i.e., arrow 1) is represented by work on identity and categorization (e.g., Tajfel \& Turner, 1979), institutions supplying basic identities and categories that, when internalized by entrepreneurial decision makers, influence entrepreneurial decisions (arrow 2).

Thus, the conditions depicted in the lower left node of Figure 1 give rise to entrepreneurial actions (the lower right node), such as the establishment of new firms or the recognition and exploitation of opportunities by existing firms (micro) that aggregate up to economy-wide outcomes, such as "churn" or economy-wide changes in productivity (macro) (i.e., arrows 1, 2, and 3). Fine-grained analysis of arrow 2 makes it clear that entrepreneurs may react

\footnotetext{
${ }^{8}$ In a relevant study of the interplay of institutions and venture capitalist behaviors in three countries, Zacharakis, McMullen, and Shepherd (2007) examined how perceptions of institutions (notably the law) influence the information venture capitalists attend to when making investment decisions, and documented the relevant crosscountry variation.
} 
differently to these conditions (McMullen \& Shepherd, 2006) depending on their level and kind of motivation (e.g., the relative roles of intrinsic and extrinsic motivation), attitude toward errors, level of prior knowledge (Shane, 2000), commitment to their venture, identity, etc. (Shepherd, 2011). These different reactions cause response heterogeneity. In turn, these reactions complicate the analysis of arrow 3 (i.e., aggregation from entrepreneurial decisions and actions to aggregate outcomes) relative to a situation where entrepreneurs can be taken to be homogeneous. For example, heterogeneity may exist with respect to persistence and commitment to failing enterprises, which introduces evolutionary (selection) considerations in the analysis of the aggregation of entrepreneurial actions (Nelson \& Winter, 1982).

In addition, the basic two-level diagram can be made more complicated in various ways. For example, additional levels can be added to it (e.g., the level of industries, networks, etc.), in effect stacking "bathtubs" vertically, or, recognizing that institutions and policies are themselves endogenous, "bathtubs" can be arranged horizontally. For example, DiMaggio (1988) and Baumol (1990) argued that entrepreneurial effort may be directed to influencing institutions and policies, and the recent literature on "institutional entrepreneurship" (Garud, Hardy, \& Maguire, 2007; Pacheco et al., 2010) amounts to the same basic idea. As noted above, this literature therefore also suggests that entrepreneurial activity and entrepreneurial problems can affect institutional choices and policy. To the extent that this occurs and represents the opposite causal influence than that shown in the figure, it creates a potential endogeneity problem.

In the next section, we use the diagram to review the existing empirical literature on the links among institutions, entrepreneurship, and growth. We do so because this literature encapsulates previous arguments based on theoretical developments. However, our gap-finding exercise has implications for both the empirical and the theoretical literature.

\section{EMPIRICAL WORK ON INSTITUTIONS, ENTREPRENEURSHIP, AND GROWTH}

To identify relevant empirical work on the institutions, entrepreneurship, and growth nexus, we did a thorough literature search based on relevant keywords in the Scopus and Web of Science databases. Our criteria for selecting studies to be covered were that papers should (1) focus on institutional characteristics, (2) include formal empirical analysis beyond simple correlations, and (3) focus on a directly demonstrated association to entrepreneurial activity and not only an interpretation consistent with effects of entrepreneurship. The third requirement means that we excluded several otherwise highly profiled papers. A recent example is Acemoglu, Akcigit, and Celik (2014), who built a theoretical model of innovation within firms and focused their empirical analysis on CEO age and characteristics. Their interpretation revolves around entrepreneurial activity but without including any direct indicators, which is a typical feature of several recent studies in both economics and business research. ${ }^{9}$ This resulted in the identification of only 28 studies, including book chapters, that directly address the aim of this paper. We summarize these studies in Appendix Table 1 and discuss the key contributions below.

\section{Pioneering Studies}

Audretsch and Acs (1994) and Audretsch and Fritsch (1994) conducted pioneering empirical studies in the stream of entrepreneurship research addressed here. Focusing on start-ups in West German regions and across 177 industries, the studies dealt primarily with convexities in production, unemployment, and capital costs. While Audretsch and Acs (1994) also found evidence that start-up activity was positively influenced by macroeconomic growth (i.e., the macro-to-micro link in Figure 1), these first studies did not focus on specific institutions or policies or assess the economic impact of entrepreneurial activity. They have, however, been followed by a long string of studies on the particular characteristics of entrepreneurs and start-up firms that more explicitly link to macro-level determinants (see, for example, the overviews in Freytag and Thurik, 2007, and Shah, Smith, and Reedy, 2012).

Other studies on the relationships among institutions/economic policy, entrepreneurship, and macroeconomic performance have focused on macro variables only. Such studies are typically cross-country or use cross-state variation within the United States. The first empirical studies of how institutions and

\footnotetext{
${ }^{9}$ Note that we have also performed searches based on more recent references to seminal papers in the entrepreneurship literature. We have thus found additional papers by starting with Scott (1995) and Kreft and Sobel (2005) and working our way forward.
} 
economic policy influence the country- or state-level incidence of entrepreneurship are Kreft and Sobel (2005) for the United States, Ovaska and Sobel (2005) for transition countries, Bjørnskov and Foss (2008) for a larger (though still small) cross-country context (27 countries), and McMullen, Bagby, and Palich (2008) for a somewhat larger context (37 countries). For conceptualizing and measuring the institutional and economic policy dimension, all four studies focused strongly on the construct of economic freedom. In this case, "economic freedom" is a situation where "individuals are permitted to choose for themselves and engage in voluntary transactions as long as they do not harm the person or property of others" (Gwartney, Hall, \& Lawson, 2014, p. 11). Accordingly, the focus in this literature is mainly on the protection of private property rights, the absence of intrusive regulations, and tax and transfer differences across countries, although the concept also includes monetary transparency and indicators of investment and trade policy.

The literature on economic and social consequences of economic freedom is rather large and growing rapidly. As the comprehensive survey in Hall and Lawson (2014) showed, almost all papers showed positive effects on growth, productivity, employment, and other macroeconomic variables of economic freedom. However, only four of the 402 studies surveyed by Hall and Lawson (2014) directly explored any relationship between economic freedom and entrepreneurship. These four studies include Kreft and Sobel (2005), Ovaska and Sobel (2005), Freytag and Thurik (2007), and Bjørnskov and Foss (2008). Incidentally, these studies arrived at somewhat opposite conclusions. While two found that low tax levels are likely to reduce entrepreneurial activity, Kreft and Sobel concluded that relative freedom from restrictive labor regulations is positively associated with entrepreneurial activity across the United States, while Bjørnskov and Foss found that the provision of sound money-low and stable inflation rates and predictable monetary policy-is positively correlated with entrepreneurial activity. ${ }^{10}$

\footnotetext{
${ }^{10}$ While not specifically addressing entrepreneurship, Ciccone and Papaioannou (2007) belong in the group of pioneering studies. They explored the determinants of establishment growth, specifically the success of start-ups. Klapper et al. (2006) likewise focused narrowly on the creation of limited liability firms. Their main result is that regulations affecting the time taken to register new businesses negatively affect entry in industries experiencing expansionary global demand.
}

\section{Later Work on Institutions, Policies, and Entrepreneurship}

A subsequent although still quite small literature develops these themes in more detail. Thus, Nyström (2008) reexamined the cross-country evidence in Bjørnskov and Foss (2008) in a much larger sample of countries, using panel data and consistently comparable self-employment rates instead of survey data from the Global Entrepreneurship Monitor database. McMullen et al. (2008) used Heritage Foundation/ Wall Street Journal economic freedom data and GEM data, regressed "opportunity" and "necessity" entrepreneurship against measures of economic freedom, and found that different freedoms affect entrepreneurship differently. A series of studies likewise reexamine themes introduced by the first studies, most of which are surveyed in Alhorr, Moore, and Payne (2008), Terjesen, Hessels, and Li (2016), and Arin, Huang, Minniti, Nandialath, and Reich (2015).

Recent studies have also explored more specific institutions and policies. For example, Djankov et al. (2010) explored the effects of effective corporate tax rates on investment, FDI, and entrepreneurial activity. They found that the corporate tax rate is particularly harmful to business entry, while other taxes also affect domestic and foreign investments in established companies. Ardagna and Lusardi (2009) instead focused on how regulations affect the selection into entrepreneurship, finding a consistently negative effect of regulations. They nevertheless also found that tighter regulations imply that female entrepreneurs start their own businesses (as necessity entrepreneurship) mainly because better employment opportunities do not exist. Moreover, individuals with good business skills and entrepreneurial networks are substantially less likely to become entrepreneurs when facing stronger regulations. Consistent with Baumol's (1990) considerations, these results suggest that regulations affect the productivity of entrepreneurship.

\section{Outcomes of Entrepreneurship}

While empirical studies have explored the effect of different institutions and policies on start-up propensity, very few studies have sought to directly estimate or even discuss the aggregate consequences, such as productivity increases, of entrepreneurship measured as a start-up activity. Part of the issue probably derives from the well-known problem of how to measure productivity at the firm, regional, or national level (Caselli, 2005; Hulten, 
2001). Productivity, or economic efficiency, is in principle easy to conceptualize by using a Solow residual (i.e., the unexplained part of economic performance when the effects of capital, labor, and other inputs have been accounted for). In practice, however, any assessment must rest on strong assumptions about, for example, how to measure education properly, whether or not to account for quality differences in capital, which functional form to employ, and how to take externalities into account when moving from the firm level to a regional or national level. Yet another reason that few studies seek to directly estimate or even discuss the aggregate consequences of entrepreneurship may be that most studies so far have simply taken the employment, productivity, or innovation effects as given, focusing on how to foster entrepreneurship (e.g., Djankov et al., 2010); in other words, their aim is not to cover all the mechanisms in Figure 1, but only the top-down ones (i.e., arrow 1).

Anokhin and Wincent (2012) produced one of the few attempts in the literature to bridge this gap. Using the GEM data for a sample of 35 countries, they assessed the effectiveness of what they termed "broadstrokes policies" aimed at promoting entrepreneurship that affects country innovativeness. They proxied differences in broad policies by the Heritage Foundation Index of Economic Freedom and a dummy for corporatist "coordinated market" economies. The authors found that policies explicitly aimed at promoting entrepreneurship are likely to be misguided because they suffer from what they call a "Hayekian design problem": It is inherently impossible for policy makers to know ex ante which start-up firms will succeed and which will not, and broad-strokes policies will therefore be designed in ways that benefit existing firms instead of potential start-ups (Hayek, 1948; Munger, 2008). In their search for policy implications, Anokhin and Wincent (2012) instead recommended more "contingent" public efforts. While such efforts that are designed to apply only to firms under very specific circumstances probably alleviate most rent-seeking problems associated with broad-strokes policies, they nevertheless suffer from severe information problems, as most simple, operational contingencies are likely to be strongly misleading (cf. Daunfeldt \& Halvorsson, 2014).

Among the few studies that have taken on this issue directly, Bjørnskov and Foss $(2012,2013)$ instead focused on the total factor productivity effects of entrepreneurial activity. Both papers first estimated the institutional effects on entrepreneurial activity and found similar results to other papers that regressed entrepreneurship data against measures of economic freedom, notably that a big public sector is harmful to the incidence of entrepreneurship. Subsequently, they estimated the average productivity consequences of entrepreneurship, finding substantial productivity increases arising from entrepreneurship. Interestingly, Bjørnskov and Foss (2013) documented that the marginal productivity effects of entrepreneurship are significantly larger in countries with large public sectors and high taxes. Although this may suggest that the public sectors in large welfare states provide services that are in some way complementary to entrepreneurship, the authors noted that the same features directly reduce entrepreneurial activity. They therefore preferred the interpretation that the higher marginal effect is due to the smaller supply of the activity-that is, a situation consistent with decreasing marginal productivity gains from entrepreneurial activity.

\section{SHORTCOMINGS AND OPEN ISSUES I: DATA AND MEASUREMENT}

In an ideal world, scholars would have completely identified all the variables and mechanisms implied in Figure 1 . While many advances have been made, we are quite far from this ideal, as indicated by the relatively small amount of empirical research work on an issue that has often been highlighted by policy makers as crucially important (OECD, 2015). The shortcomings and open issues are conceptual, theoretical, methodological, and empirical. However, they are closely linked, as, for example, data availability may steer theorizing in one direction rather than another. In this section, we review and exemplify these problems.

\section{Dependent Variable: Entrepreneurship}

A key problem with taking entrepreneurship as a dependent variable is related to the choice of relevant measures of entrepreneurial activity/decisions/ actions-that is, the lower right node in Figure 1. Entrepreneurship can be measured in a multitude of ways, depending on the theoretical perspective. For example, while labor economists may prefer measuring potentially productive entrepreneurship in terms of self-employment, other economists may prefer to measure it as start-up activity. Management scholars inspired by Kirzner (1973) tend to highlight the discovery of opportunities, while others inspired by a more Knightian approach (e.g., Foss \& Klein, 2012) may prefer to measure it in terms of the actual investments dedicated to the pursuit of imagined 
opportunities. Obviously, measures will differ widely based on these different conceptualizations. In addition, some economists (Baumol, 1993; Schumpeter, 1939, 1942) and management scholars (Foss \& Lyngsie, 2014) have highlighted the ability of established firms to engage in entrepreneurship and will reject measures that address only start-up activity. ${ }^{11}$

Actual measurement is usually a compromise between the theoretical perspective and available measures. Most of the studies summarized in Appendix Table 1 used either survey-based measures of intending to or being in the process of starting up an enterprise (mostly based on the GEM) or measures of self-employment, micro-firms (with fewer than five employees), or start-ups. While such measurement is consistent with a labor economics approach that conceptualizes entrepreneurship in terms of occupational choice (Parker, 2005), it has difficulties capturing at least two other important views of entrepreneurship: Kirzner's $(1973,1997)$ view that entrepreneurship can be exercised by ("poor and penniless") individuals by means of arbitrage and does not logically require the formation of a new firm, and the view that entrepreneurship can be performed by established firms (Baumol, 1993; Foss \& Lyngsie, 2014; Schumpeter, 1942).

It is far from clear how the Kirznerian view of entrepreneurship can be operationalized and measured. Some aspects are captured by choosing to become self-employed; as such, this is captured by public registers in many countries. However, fleeting, informal arbitrage activities, perhaps taking place in the gray or black sectors of the economy, are more likely to escape serious measurement (Antunes \& Cavalcanti, 2007). In addition, Henrekson and Sanandaji (2014) argued that self-employment measures also fail to capture the effects of what they term "high-impact Schumpeterian entrepreneurship"that is, entrepreneurial activity that destroys old firms but provides great societal benefits. ${ }^{12}$

Measuring the entrepreneurial activities of established firms remains a challenge (e.g., Decker et al.,

\footnotetext{
${ }^{11}$ We refrain from discussing the additional complications of measuring unproductive and destructive entrepreneurship (Baumol, 1990). Such activities are well described in public choice and political economy traditions, and are mostly equated with a variety of lobby activities. Young and Wiseman (2014) made a recent attempt to separate productive and unproductive entrepreneurship in the United States.

${ }^{12}$ Their new alternative is to measure the number of billionaires in each society (Sanandaji \& Leeson, 2014).
}

2014; Foss \& Lyngsie, 2014). Patent activity and research and development (R\&D) expenditures provide some of the most widely employed measures, but neither patents nor R\&D expenditures measure innovation or entrepreneurship per se. Additionally, as Schumpeter (1911) clarified, entrepreneurship goes beyond innovation and includes, for example, discovering new markets, suppliers, market channels, and organization forms. However, the literature lacks scales that allow for tapping into entrepreneurial outcomes at the firm level. Foss, Lyngsie, and Zahra (2013) applied a count measure based on questions to CEO respondents regarding the number of opportunities they successfully realized in the previous three years. Apart from obvious problems of recall bias, such a measure lumps together very small opportunities with large opportunities. Thus, a firm that has successfully realized five trivial opportunities appears more entrepreneurial than one that has realized a truly major opportunity. The development of valid and reliable measurement scales of established firm entrepreneurship remains a major challenge.

\section{Dependent Variable: Aggregate Outcomes}

On the economy level, outcomes can be measured in many different ways, depending on interests, context, and data availability (e.g., job creation, firm growth, innovative entry, innovation activity, and productivity advances) (Arzeni, 1997; Baptista, Escária, \& Madruga, 2008; Capelleras et al. 2007; Erken, Donselaar, \& Thurik, 2008; Klein \& Luu, 2003). In the labor economics, trade studies, and industrial economics fields, large-scale firm-level and industry-level datasets exist and have been used extensively by economists and management scholars alike. However, the use of these data sources in entrepreneurship studies remains in its infancy because new firms often enter datasets only after some period of time. Notably, failing start-ups may go unregistered, and the standard use of small business statistics can hide very large and consequential differences between small and young firms (Decker et al., 2014).

\section{Causality}

A distinct challenge in the literature is how to identify and document causality. This is partly a theoretical issue and partly an empirical challenge. For example, entrepreneurship may be both a cause and a consequence of economic growth. Indeed, Audretsch and Acs (1994) suggested that entrepreneurship reacts 
positively to economic growth, as a growing economy offers more opportunity. On the other hand, as highlighted by theoretical work (Aghion \& Howitt, 1992; Schumpeter, 1911), recent empirical studies instead show that entrepreneurial activity affects long-run growth and productivity—that is, the opposite causal association (cf. Bjørnskov \& Foss, 2012; Koellinger \& Thurik, 2012).

Causality issues are also manifest in the link between institutions and entrepreneurship. Thus, Baumol's work (1990) and the recent literature on institutional entrepreneurship (Li, Feng, \& Jiang, 2006) suggest that entrepreneurship may not just be endogenous to institutions; institutions may also be endogenous to entrepreneurship (Pacheco et al., 2010). For example, Dean and McMullen (2007) argued that externality problems and other market failures may represent entrepreneurial opportunities. Institutional entrepreneurs may seize such opportunities by enacting institutions that help internalize the relevant externalities (what Dean and McMullen called "sustainable entrepreneurship").

A different take on the relationship between entrepreneurs and institutions is represented by public choice theory, which implies that established industries typically form strong and influential lobby groups that can affect-and in some cases definethe regulatory framework and specific legislation (Olson, 1982; Stigler, 1971). A lack of entrepreneurial activity and productivity gains can therefore easily lead to persistent lobbying for institutional change to prevent the entry of new and more productive or innovative firms (e.g., Baumol, 1990; Hillman, 1982). Conversely, making a clean break with special interests and policies can, in principle, provide substantial impetus for firm creation and entrepreneurial activity. However, the endogeneity problem creates a need to find either specific circumstances in which institutions are not affected by existing conditions or where other information allows the identification of mono-causal effects.

\section{Omitted-Variable Bias}

As in many other fields, such as the literature on regional and national productivity and development accounting (Caselli, 2005; Klenow \& RodriguezClare, 1997), the entrepreneurship literature has not converged on a consensus on what to consider as a standard or even minimalist empirical specification. As such, all studies risk suffering from omittedvariable bias, which necessitates careful robustness analysis (cf. Dreher \& Gassebner, 2013). Among the variables that are characteristically omitted in the studies surveyed in Appendix Table 1 are cultural features, trade flows and policy, the initial technological level of the country, factor endowments, and proxies for the ease of information flows. The type of robustness studies pioneered in growth studies by Levine and Renelt (1992) and Sala-i-Martin (1997), in which researchers expose their main results and preferred specifications to extensive sets of additional, potentially influential factors and empirical alternatives, remain entirely absent in the literature on entrepreneurship.

\section{Multilevel Designs}

Similarly, as noted above, many studies do not bring micro-data into the analysis even though multilevel analysis may in many cases be both feasible and desirable. This lacuna is not merely a source of omittedvariable bias in cross-state and cross-country studies. As represented in the diagram in Figure 1, the relationships among institutions, entrepreneurship, and aggregate outcomes are, as a logical matter, multilevel (Shepherd, 2011). Thus, entrepreneurial conditions and actions are nested in higher-level entities, such as nationally defined institutions and policies as well as international business cycle fluctuations. Yet part of the challenge of dependable multilevel analysis lies in the question of when new firms enter official registers and statistics (Decker et al., 2014); another part rests in the practical difficulties in separating apparent short-term success from long-term productive contributions and sustainable business growth (Daunfeldt \& Halvorsson, 2014).

\section{Response Heterogeneity}

Regardless of which level of analysis scholars address, a specific shortcoming in the literature is an important assumption that mostly goes undiscussed (but see McMullen \& Shepherd, 2006; Zacharakis et al., 2007): that studies assume that the responses to institutional and policy differences are approximately homogeneous across different types of industries, businesses, and countries and institutional settings. Almost all empirical studies therefore merely identify average treatment effects that can easily hide very different effects across industries or countries and, in cases where actual effects are heterogeneous, create substantial measurement error. Related to the entrepreneurship literature, studies for example find that heavy business and credit regulations and poor protection of private property rights can be a detriment to 
entrepreneurial activity and in particular the growth of new firms (De Soto, 2000), but more so when smallscale business owners cannot bribe their way around these institutional problems (Bologna \& Ross, 2015). Similarly, certain policies and institutions may have different effects depending on the quality of other institutions.

Additionally, as shown by Bjørnskov and Foss (2013), which is the only paper in Appendix Table 1 that explicitly deals with the heterogeneity problem, productivity inferences can be misleading if researchers do not know the effects on both the supply and characteristics of entrepreneurial activity. Finding that certain welfare state policies are positively associated with the marginal productivity effect of entrepreneurship may therefore not be evidence of positive effects of welfare policies, but rather of an interaction between the effects on the quantity and quality of entrepreneurial activity. Generous benefits systems and high and progressive taxation merely drive out the relatively less productive startup firms. Such interactions across levels of analysis and different institutional characteristics remain almost entirely absent from the entrepreneurship literature.

\section{Sample Frames and Data Limitations}

A final problem that deserves mention derives from the fact that despite the impressive growth of data and data availability, only very few databases provide specialized information on entrepreneurial activity, firm growth, and start-ups. Sampling remains a particular problem of studying new firms and innovative activity in small or relatively young firms, as sampling procedures in most cases exclude the smallest, youngest, and hardest-to-find entities. Most studies use either survey data from GEM or self-employment rates across OECD countries, although both survey evidence on stated intentions and a focus on small firms may be misleading. For example, Decker et al. (2014) showed that productivity differences in the United States arise from young firms instead of small firms. As most young firms are small, what arguably drives entrepreneurial productivity effects thus arises from a subset of self-employed individuals or very small firms. The real effects of start-ups will therefore be underestimated when employing the standard approach in the current literature. However, to distinguish between different types of firms, it is necessary to observe firms from their infancy.

In the context of data on institutions and institutional characteristics, two problems persist: (1) the problem of how best to measure institutions, and in particular how to separate de jure features from de facto implementation and execution (Voigt, 2013), and (2) the extent to which institutional details are known and available to researchers. While data limitations are often treated as a rather mundane problem, they must be carefully addressed before any of the other shortcomings of the literature can be alleviated.

\section{Summing Up}

To some extent, the above gaps and shortcomings reflect the fact that entrepreneurship research in management has tended to focus on different issues and different levels of analysis and measurement than that in economics. Measurement problems and conceptual issues have often been carefully dealt with in a number of management studies, but perhaps remain somewhat less developed in the economic part of the field. Conversely, specification issues and the causality problem are traditionally particularly salient among economists and have arguably, on average, been more thoroughly addressed in that part of the literature. Yet other problems are common for all studies regardless of whether they originate in management science or economics. These include a lack of detailed micro-level data beyond case studies, the interaction between macrolevel institutions and policies and firm-level responses, and in particular the potentially complex interactions between different institutions and policies. The relative absence of studies of the interactions between macro-level institutions and policies and firm-level responses also prevent more detailed work in transmission mechanisms (at the micro level of Coleman's bathtub in Figure 1) connecting institutions and entrepreneurial outcomes. Any discussion of optimal institutional and policy design is out of reach before substantially more is known about these transmission mechanisms. In the following section, we argue that extant management research can contribute important insights to the theoretical understanding of these mechanisms.

\section{SHORTCOMINGS AND OPEN ISSUES II: THEORETICALLY UNDERSTANDING TRANSMISSION MECHANISMS}

\section{Factors in the Growth Process}

The understanding of the growth process has traditionally proceeded on a high level of aggregation 
(i.e., arrow 4 in Figure 1), with little attention being paid to the micro-aspects of the complex transmission mechanisms between institutions and policies and economic growth. The growth literature in economics has traditionally been divided between scholars who stress the role of capital accumulation in the growth process (Lucas, 1988) and those who stress "technology" (Solow, 1956, 1957) and the many other factors that cannot be understood in terms of the accumulation of capital and improvement of, or increases in the supply of, human capital (Bjørnskov \& Foss, 2013). The latter group of scholars thinks of the growth process in terms of improvements in "total factor productivity." This traditionally refers to the output changes that cannot be ascribed to changes in traditional production factors (labor, capital, land). There is evidence that the main factor that accounts for different growth experience across countries is the difference in total factor productivity (Parente \& Prescott, 2005).

\section{Entrepreneurial Resource Combination}

Discussions of total factor productivity and the growth process have often highlighted R\&D and the innovations that emerge from R\&D (e.g., Romer, 1990). Innovations are, of course, introduced by firms and also include nonscience-based innovations (e.g., many process and organizational innovations). As Foss and Klein (2012) argued, these processes are entrepreneurial ones; specifically, they involve experimenting with the combination and recombination of heterogeneous resources in the pursuit of profits under uncertainty (Agarwal, Barney, Foss, \& Klein, 2009; Rumelt, 1987). In the aggregate (i.e., arrow 3 in Figure 1), these processes lead to the productivity advances and improvements in resource utilization that are significant parts of increases in total factor productivity. This suggests that the resource-based view, which stresses fundamental resource heterogeneity, has insights to offer on the micro-mechanisms of the growth process. This requires a break with certain aspects of the production function framework that has dominated postwar economics. Thus, this framework takes resources to be homogeneous within categories (land, labor, capital) and assumes that resources are always combined in the best possible manner. In Olson's (1996) words, the traditional framework explicitly assumes that big bills are not "left on the sidewalk.","

\footnotetext{
${ }^{13}$ These words appear in the title of Olson's 1996 article in the Journal of Economic Perspectives.
}

This standard framework has the unfortunate consequence that it becomes hard to define a meaningful role for the entrepreneur (cf. Agarwal et al., 2009). In actuality, resources are of course heterogeneous (Barney, 1991; Lachmann, 1956), and combining them in the uncertain pursuit of profits constitutes the essence of enterprise (Foss \& Klein, 2012; Knight, 1921). Because of uncertainty and asymmetric information, the optimal combination of resources is not a given (as in the economics of production), but is something that at best can be approached through managerial processes of resource experimentation. Thus, as argued by Foss and Klein (2012), processes of mergers, divestments, spin-offs, new firm formation, etc., reallocate resources across firms in response to price signals and entrepreneurial behaviors, and make the economy track its (moving) production possibility frontier (e.g., Foster, Haltiwanger, \& Krizan, 2002).

\section{The Role of Institutions}

Experimental processes of resource combination are influenced by institutions and policy (i.e., arrow 1 in Figure 1). In general, there is much evidence that institutions have a strong impact on growth (see, in particular, Rodrik, Subramanian, \& Trebbi, 2004). As North (1990, p. 6) explained, "The major role of institutions in a society is to reduce uncertainty by establishing a stable (but not necessarily efficient) structure to human interaction. The overall stability of an institutional framework makes complex exchange possible across both time and space." Such higher certainty translates into lowered transaction costs. Specifically, higher certainty means that the costs of contracting and of protecting property are lowered, which in turn means that more entrepreneurial projects will be undertaken. As Bjørnskov and Foss (2013) argued, higher certainty and incentives for productive behaviors are particularly strongly influenced by the extent to which private property rights are protected, including dimensions such as generality (i.e., equals are treated equally), transparency and accountability in public decision making, and, importantly, an expectation that property rights are effectively enforced.

While many social scientists have made similar points, the ways in which institutions and entrepreneurial activities are related have seldom been pinned down with much precision (for some recent attempts, see Henrekson, 2005). If one accepts the argument that economic growth is to a large extent the result of the introduction of new modes of 
organization, ways of better allocating resources to preferred uses, and so on, the flexibility (i.e., costliness) with which these changes can be made becomes a central concern (Bjørnskov \& Foss, 2013). Economic production theory captures such flexibility with the notion of the "elasticity of factor substitution" (Klump \& de La Grandville, 2000). ${ }^{14}$ A high elasticity of substitution means high factor productivity, as resources are more easily allocated to highly valued uses. The elasticity of substitution is not a purely technical parameter and is endogenous to institutional variables. Institutions that lower the transaction costs for searching for contract partners, bargaining, and monitoring and enforcing contracts, positively influence the ease, speed, and flexibility with which resources can be identified, allocated, combined, etc. by these entrepreneurs. In other words, such institutions imply that the elasticity of substitution is high, and hence positively influence total factor productivity. Low transaction costs result from welldefined and enforced property rights. Thus, institutional and political features, such as the quality of regulations and the judicial system, that directly influence property rights influence the relationship between entrepreneurship and total factor productivity, and therefore growth.

\section{Summing Up}

Bjørnskov and Foss (2013) made use of arguments such as the ones above in linking their institutional measures (mainly "freedom variables" relating to regulatory quality, the size of government, sound money, etc., but also measures such as the extent of foreign trade). However, the theorized mechanisms remain unobserved in their work. This is significant because it points to both the lack of theorizing of the mechanisms that traverse levels and the absence of appropriately nested data across a sufficient number of countries (or regions) that can be used to test and otherwise further theorizing in this domain, as we pointed out earlier. We are, however, optimistic concerning progress in this area. First, data relevant to understanding the mechanics of the growth process have increasingly become available, and there is no reason to think that relevant multilevel datasets will remain unavailable. Second, theorizing the relevant inter-level mechanisms will, we suggest, require the integration of the economics of institutions

\footnotetext{
${ }^{14}$ This elasticity measures the percentage change in factor proportions due to a change in marginal rate of technical substitution.
}

and growth with management research insight into entrepreneurship and resource allocation in firms. As economists increasingly question the traditional production function view of firms (Williamson, 1985) and as management scholars increasingly adopt rigorous methods, we are confident that such a combined enterprise will not only be possible but will be successful as well.

\section{CONCLUSION}

The ultimate purpose of a structured survey of a literature is to provide an overview that allows readers to form a sense of the shortcomings of this literature and how these may be addressed. In other words, the main question of this paper is what the literature so far has not addressed and how best to meet the challenge of moving closer to a real understanding of the links between institutions, entrepreneurship, and subsequent economic performance. In this concluding discussion we further reflect on some of the major challenges left in the literatures. We specifically identify five related gaps.

First, as Casson and Wadeson (2007, pp. 239-240) emphasized, growth is an important political objective, but "entrepreneurship is most often used to explain differences between countries (and regions) in levels of economic activity." Thus, there is little emphasis on growth. This may be a consequence of the relative absence of theoretical development providing clear guidelines for empirical studies of the association between growth and entrepreneurial activity. The line of research started by Aghion and Howitt (1992) to some extent rises to this challenge by building from the Schumpeterian concept of creative destruction (Schumpeter, 1911). However, the difficulty of modeling creative destruction has limited its direct applicability, and most of the implications that empirical researchers have drawn from this tradition have focused on institutional constraints to growth.

A second but related gap arises as current performance (in terms of either economic activity or productivity) can be seen as the compounded influence of entrepreneurship and other influences. Focusing on current performance instead of growth can therefore be very misleading, as it is the result of past institutions and policies that may not even exist anymore. Relatedly, as stressed by Bjørnskov and Foss (2013), institutions and policies may both moderate and mediate the effects of entrepreneurship on growth and performance. Several studies have documented that institutions can affect the 
supply of entrepreneurship, whereas very few studies have tested whether the impact of entrepreneurial activity is systematically heterogeneous across different institutions, although this point was originally stressed in Baumol's (1990) seminal work. Yet these studies suggest that one of the mechanisms connecting good judicial and market institutions to subsequent growth may be the way these institutions advance productive entrepreneurship. Theoretically, the understanding of such institutional complementarities, though highlighted by economics historians for decades (e.g., Mokyr, 2009; North, 1990), is in its infancy.

A third gap exists because many of the mechanisms hiding in the arrows of Figure 1 are not clearly theorized. For example, institutions and policies may influence the incidence of entrepreneurship in multiple ways, some direct, some more indirect. Intellectual property rights (IPR) regimes and tax policies may have very direct effects; for example, high taxation makes it difficult to accumulate the savings that may be required for launching a start-up (Henrekson, 2005), while weak IPR regimes may reduce the expected rents from innovative entrepreneurship. However, informal institutions such as generalized trust or social norms may have more indirect effects (cf. Scott, 1995). Such institutions reduce the costs of searching for (trustworthy) contracting partners and reduce the costs of bargaining, monitoring, and enforcing contracts (Ikeda, 2008; Williamson, 1996). In turn, this increases the aggregate elasticity of substitution of the economy, as we argued.

Fourth, only very few of the papers we surveyed deal with the causality issue inherent in assessing effects of institutions and entrepreneurship, and more than half do not even mention the problem. To some extent, this reflects different traditions across fields, with economics having developed extreme standards of causal identification in recent decades. But it also reflects that mechanisms are undertheorized, such that an otherwise rich theoretical literature provides only weak guidelines for dealing with the issue.

Finally, the entrepreneurship literature tends to suffer from the same problem as other fields that are taken up with the consequences of institutional differences. The concept of institutions and institutional quality is treated very differently, ranging from a Northian understanding in most of economics (North, 1990) to a substantially broader concept in sociology (cf. Scott, 1995) and a generally vague separation of market and government institutions, as well as an unclear separation of formal and informal institutions (Voigt, 2013). Scholars who work on institutions and entrepreneurship thus risk engaging in conceptual stretching, which further exacerbates the problem of under-theorizing when what is meant by the very term "institutions" remains unclear and poorly delineated.

Despite the gaps outlined here, the literature on entrepreneurship, institutions, and aggregate economic performance has made many important strides. There is very substantial evidence backing the claim that entrepreneurial activity has positive long-run economic consequences in terms of wealth, productivity, and growth. Institutions advance the level of entrepreneurial activity and may also channel entrepreneurship in productive, rather than unproductive, directions. However, exactly which institutional elements are more important for bringing about these beneficial consequences remains an open question. As signaled already, we are, nevertheless, optimistic concerning progress in this area, as highquality data increasingly become available and as social scientists increasingly open up the black boxes of inter-firm mechanisms, likely in joint research endeavors across disciplines and fields.

\section{REFERENCES}

Acemoglu, D., Akcigit, U., \& Celik, M. A. (2014). Young, restless and creative: Openness to disruption and creative innovations (NBER Working Paper 19894). Cambridge, MA: National Bureau of Economic Research.

Acs, Z. J., Braunerhjelm, P., Audretsch, D. B., \& Carlsson, B. (2009). The knowledge spillover theory of entrepreneurship. Small Business Economics, 32, 15-30.

Acs, Z. J., Lee, S. Y., \& Florida, R. (2004). Creativity and entrepreneurship. Regional Studies, 38, 879-891.

Acs, Z. J., Morck, R. K., \& Yeung, B. (2001). Entrepreneurship, globalization, and public policy. Journal of International Management, 7, 235-251.

Agarwal, R., Audretsch, D., \& Sarkar, M. B. (2010). Knowledge spillovers and strategic entrepreneurship. Strategic Entrepreneurship Journal, 4, 271-283.

Agarwal, R., Barney, J. B., Foss, N. J., \& Klein, P. (2009). Heterogeneous resources and the financial crisis: Implications of strategic management theory. Strategic Organization, 7, 467-484.

Aghion, P., Akcigit, U., \& Howitt, P. (2014). What do we learn from Schumpeterian growth theory? In P. Aghion \& S. N. Durlauf (Eds.), Handbook of economic growth (Vol. 2, pp. 515-563). Amsterdam: Elsevier.

Aghion, P., \& Durlauf, S. N. (Eds.). (2015). Handbook of economic growth. Oxford, UK: Oxford University Press. 
Aghion, P., \& Howitt, P. (1992). A model of growth through creative destruction. Econometrica, 60, 323-351.

Aghion, P., \& Howitt, P. (1998a). Capital accumulation and innovation as complementary factors in long-run growth. Journal of Economic Growth, 3, 111-130.

Aghion, P., \& Howitt, P. (1998b). Endogenous growth theory. Cambridge, MA: MIT Press.

Aldrich, H. (2011). An evolutionary approach to entrepreneurship: Selected essays of Howard Aldrich. Aldershot, UK: Edward Elgar.

Alhorr, H. S., Moore, C. B., \& Payne, G. T. (2008). The impact of economic integration on cross-border venture capital investments: Evidence from the European Union. Entrepreneurship Theory and Practice, 32, 897-917.

Anokhin, S., \& Wincent, J. (2012). Start-up rates and innovation: A cross-country examination. Journal of International Business Studies, 43, 41-60.

Antunes, A. R., \& Cavalcanti, T. V. V. (2007). Start-up costs, enforcement, and the hidden economy. European Economic Review, 51, 203-224.

Aparicio, S., Urbano, D., \& Audretsch, D. (in press). Institutional factors, opportunity entrepreneurship and economic growth: Panel data evidence. Technological Forecasting and Social Change.

Ardagna, S., \& Lusardi, A. (2009). Where does regulation hurt? Evidence from new businesses across countries (NBER Working Paper 14747). Cambridge, MA: National Bureau of Economic Research.

Arin, K. P., Huang, V. Z., Minniti, M., Nandialath, A. M., \& Reich, O. F. M. (2015). Revisiting the determinants of entrepreneurship: A Bayesian approach. Journal of Management, 41, 607-631.

Arzeni, S. (1997). Entrepreneurship and job creation. The OECD Observer, 209, 18-20.

Audretsch, D. B., \& Acs, Z. J. (1994). New-firm startups, technology, and macroeconomic fluctuations. Small Business Economics, 6, 439-449.

Audretsch, D. B., \& Fritsch, M. (1994). The geography of firm births in Germany. Regional Studies, 28, 359-365.

Audretsch, D. B., Keilbach, M., \& Lehmann, E. (2006). The knowledge spillover theory of entrepreneurship and economic growth. Economia e Politica Industriale, 3, $25-45$.

Avnimelech, G., Zelekha, Y., \& Sharabi, E. (2014). The effect of corruption on entrepreneurship in developed vs. non-developed countries. International Journal of Entrepreneurial Behavior \& Research, 20, 237-262.

Baptista, R. V., Escária, V., \& Madruga, P. (2008). Entrepreneurship, regional development and job creation:
The case of Portugal. Small Business Economics, 30, 49-58.

Barney, J. B. (1991). Firm resources and sustained competitive advantage. Journal of Management, 17, 99-120.

Barro, R. J. (1991). Economic growth in a cross-section of countries. Quarterly Journal of Economics, 106, 407443.

Baumol, W. J. (1990). Entrepreneurship: Productive, unproductive and destructive. Journal of Political Economy, 98, 893-921.

Baumol, W. J. (1993). Entrepreneurship, management, and the structure of payoffs. Cambridge, MA: MIT Press.

Baumol, W. J., Litan, R. E., \& Schramm, C. J. (2007). Good capitalism, bad capitalism, and the economics of growth and prosperity. New Haven, CT: Yale University Press.

Bianchi, M., \& Henrekson, M. (2005). Is neoclassical economics still entrepreneurless? Kyklos, 58, 353-377.

Bjørnskov, C., \& Foss, N. J. (2008). Economic freedom and entrepreneurial activity: Some cross-country evidence. Public Choice, 134, 307-328.

Bjørnskov, C., \& Foss, N. J. (2012). How institutions of liberty promote entrepreneurship and growth. In F. McMahon (Ed.), Economic freedom of the world: 2012 annual report. Vancouver, Canada: Fraser Institute.

Bjørnskov, C., \& Foss, N. J. (2013). How strategic entrepreneurship and the institutional context drive economic growth. Strategic Entrepreneurship Journal, 7, 50-69.

Blanchflower, D. G. (2000). Self-employment in OECD countries. Labour Economics, 7, 471-505.

Blau, D. (1987). A time-series analysis of self-employment in the United States. Journal of Political Economy, 95, 445-467.

Bologna, J., \& Ross, A. (2015). Corruption and entrepreneurship: Evidence from a random audit program. Public Choice, 165, 59-77.

Bowen, H. P., \& De Clercq, D. D. (2008). Institutional context and the allocation of entrepreneurial effort. Journal of International Business Studies, 39, 747767.

Capelleras, J.-L., Mole, K. F., Greene, F. J., \& Storey, D. J. (2007). Do more heavily regulated economies have poorer performing new ventures? Evidence from Britain and Spain. Journal of International Business Studies, 37, 1-17.

Caselli, F. (2005). Accounting for cross-country income differences. In P. Aghion \& S. N. Durlauf (Eds.), Handbook of economic growth (Vol. 1B, pp. 679-742). Amsterdam: Elsevier. 
Casson, M. C. (1982). The entrepreneur: An economic theory. Oxford, UK: Martin Robertson.

Casson, M. C., \& Wadeson, N. (2007). Entrepreneurship and macroeconomic performance. Strategic Entrepreneurship Journal, 1, 239-262.

Ciccone, A., \& Papaioannou, E. (2007). Red tape and delayed entry. Journal of the European Economic Association, 5, 444-458.

Coleman, J. D. (1990). Foundations of social theory. Cambridge, MA: Harvard University Press.

Cosgel, M. (1996). Metaphors, stories and the entrepreneur in economics. History of Political Economy, 28, 57-76.

Dau, L. A., \& Cuervo-Cazurra, A. (2014). To formalize or not to formalize: Entrepreneurship and pro-market institutions. Journal of Business Venturing, 29, 668-686.

Daunfeldt, S.-O., \& Halvorsson, D. (2014). Are high-growth firms one-hit wonders? Evidence from Sweden. Small Business Economics, 44, 361-383.

Dean, T. J., \& McMullen, J. S. (2007). Toward a theory of sustainable entrepreneurship: Reducing environmental degradation through entrepreneurial action. Journal of Business Venturing, 22, 50-76.

Decker, R., Haltiwanger, J., Jarmin, R., \& Miranda, J. (2014). The role of entrepreneurship in US job creation and economic dynamism. Journal of Economic Perspectives, 28, 3-24.

Denzau, A., \& North, D. C. (1994). Shared mental models: Ideologies and institutions. Kyklos, 47, 3-31.

De Soto, H. (2000). The mystery of capital: Why capitalism triumphs in the West and fails everywhere else. New York: Basic Books.

DiMaggio, P. (1988). Interest and agency in institutional theory. In L. Zucker (Ed.), Institutional patterns and organizations (pp. 3-21). Cambridge, MA: Ballinger.

Djankov, S., Ganser, T., McLiesh, C., Ramalho, R., \& Shleifer, A. (2010). The effect of corporate taxes on investment and entrepreneurship. American Economic Journal: Macroeconomics, 2, 31-64.

Dove, J. A. (2015). The effect of judicial independence on entrepreneurship in the US states. Economic Systems, 39, 72-96.

Dreher, A., \& Gassebner, M. (2013). Greasing the wheels? The impact of regulations and corruption on firm entry. Public Choice, 155, 413-432.

Erken, H., Donselaar, P., \& Thurik, R. (2008). Total factor productivity and the role of entrepreneurship (Discussion Paper). Amsterdam: Tinbergen Institute.

Foss, N. J., \& Klein, P. G. (2012). Organizing entrepreneurial judgment: A new theory of the firm. Cambridge, UK: Cambridge University Press.
Foss, N. J., \& Klein, P. G. (in press). Entrepreneurial opportunities: In search of the middle ground. Academy of Management Review.

Foss, N. J., \& Lyngsie, J. (2012). Strategic entrepreneurship: An emerging approach to firm-level entrepreneurship. In D. Hjorth (Ed.), Handbook on organisational entrepreneurship (pp. 208-225). Cheltenham, UK: Edward Elgar Publishing.

Foss, N. J., \& Lyngsie, J. (2014). The strategic organization of the entrepreneurial established firm. Strategic Organization, 12, 208-215.

Foss, N. J., Lyngsie, J., \& Zahra, S. (2013). The role of external knowledge sources and organizational design in the process of opportunity exploitation. Strategic Management Journal, 34, 1453-1471.

Foster, L., Haltiwanger, J. C., \& Krizan, C. J. (2002). The link between aggregate and micro productivity growth: Evidence from retail trade (Working Paper 9120). Cambridge, MA: National Bureau of Economic Research.

Freytag, A., \& Thurik, R. (2007). Entrepreneurship and its determinants in a cross-country setting. Journal of Evolutionary Economics, 17, 117-131.

Garud, R., Hardy, C., \& Maguire, S. (2007). Institutional entrepreneurship as embedded agency: An introduction to the special issue. Organization Studies, 28, 957-969.

Gohmann, S. F. (2012). Institutions, latent entrepreneurship, and self-employment: An international comparison. Entrepreneurship Theory and Practice, 36, 295-321.

Grilo, I., \& Irigoyen, J. M. (2006). Entrepreneurship in the EU: To wish and not to be. Small Business Economics, 26, 305-318.

Gwartney, J. D., Hall, J., \& Lawson, R. (2014). Economic freedom of the world: 2014 annual report. Vancouver, Canada: The Fraser Institute.

Hall, J., \& Lawson, R. (2014). Economic freedom of the world: An accounting of the literature. Contemporary Economic Policy, 32, 1-19.

Hayek, F. A. (1945). The use of knowledge in society. American Economic Review, 35, 519-530.

Hayek, F. A. (1948). Individualism and economic order. Chicago: University of Chicago Press.

Hayek, F. A. (1973). Law, legislation, and liberty: Rules and order (Vol. 1). Chicago: University of Chicago Press.

Henrekson, M. (2005). Entrepreneurship: A weak link in the welfare state? Industrial and Corporate Change, 14, 437-467.

Henrekson, M., \& Sanandaji, T. (2010). Institutional entrepreneurship: An introduction (IFN Working Paper). Stockholm: Research Institute of Industrial 
Economics (IFN). Retrieved from http://papers.ssrn. com/sol3/papers.cfm?abstract_id $=1689034$

Henrekson, M., \& Sanandaji, T. (2014). Small business activity does not measure entrepreneurship. Proceedings of the National Academy of Sciences of the United States of America, 111, 1760-1765.

Hillman, A. L. (1982). Declining industries and politicalsupport protectionist motives. American Economic Review, 72, 1180-1187.

Holcombe, R. (1998). Entrepreneurship and economic growth. Quarterly Journal of Austrian Economics, 1, 45-62.

Holmes, T. J., \& Schmitz, J. A. (1990). A theory of entrepreneurship and its application to the study of business transfers. Journal of Political Economy, 98, 265-294.

Hulten, C. R. (2001). Total factor productivity: A short biography. In C. R. Hulten, E. R. Dean, \& M. J. Harper (Eds.), New developments in productivity analysis (pp. 1-45). Cambridge, MA: NBER Books.

Ikeda, S. (2008). The meaning of "social capital” as it relates to the market process. Review of Austrian EConomics, 21, 167-182.

Kaul, A. (2013). Entrepreneurial action, unique assets, and appropriation risk: Firms as a means of appropriating profit from capability creation. Organization Science, 24, 1765-1781.

Kihlström, R. E., \& Laffont, J.-J. (1979). A general equilibrium entrepreneurial theory of firm formation based on risk aversion. Journal of Political Economy, 87, 719-748.

Kirzner, I. M. (1973). Competition and entrepreneurship. Chicago: University of Chicago Press.

Kirzner, I. M. (1980). The prime mover of progress. In I. Kirzner \& A. Seldon (Eds.), The entrepreneur in capitalism and socialism. London: Institute of Economic Affairs.

Kirzner, I. M. (1997). Entrepreneurial discovery and the competitive market process: An Austrian approach. Journal of Economic Literature, 35, 60-85.

Klapper, L., Laevena, L., \& Rajan, R. (2006). Entry regulation as a barrier to entrepreneurship. Journal of Financial Economics, 82, 591-629.

Klein, P. G. (2008). Opportunity discovery, entrepreneurial action, and economic organization. Strategic Entrepreneurship Journal, 2, 175-190.

Klein, P. G., \& Luu, H. (2003). Politics and productivity. Economic Inquiry, 41, 433-447.

Klein, P. G., Mahoney, J. T., McGahan, A. M., \& Pitelis, C. N. (2010). Toward a theory of public entrepreneurship. European Management Review, 7, 1-15.

Klenow, P. J., \& Rodriguez-Clare, A. (1997). The neoclassical revival in growth economics: Has it gone too far? In B. S. Bernanke \& J. Rotenberg (Eds.), NBER macroeconomics annual (Vol. 12, pp. 73-114). Boston: MIT Press.

Klump, R., \& de La Grandville, O. (2000). Economic growth and the elasticity of substitution: Two theorems and some suggestions. American Economic Review, 90, 282-291.

Knight, F. H. (1921). Risk, uncertainty, and profit. New York: Augustus M. Lelley.

Koellinger, P. D., \& Thurik, A. R. (2012). Entrepreneurship and the business cycle. Review of Economics and Statistics, 94, 1143-1156.

Kreft, S. F., \& Sobel, R. S. (2005). Public policy, entrepreneurship, and economic freedom. Cato Journal, 25, 595-616.

Lachmann, L. M. (1956). Capital and its structure. Kansas City, MO: Sheed Andrews and McMeel.

Landes, D. S., Mokyr, J., \& Baumol, W. J. (2010). The invention of enterprise: Entrepreneurship from ancient Mesopotamia to modern times. Princeton, NJ: Princeton University Press.

Levie, J., Autio, E., Acs, Z. J., \& Hart, M. (2014). Global entrepreneurship and institutions: An introduction. Small Business Economics, 42, 437-444.

Levine, R., \& Renelt, D. (1992). A sensitivity analysis of cross-country growth regressions. American ECOnomic Review, 82, 942-963.

Li, D. D., Feng, J., \& Jiang, H. (2006). Institutional entrepreneurs. American Economic Review, 96, 358-362.

Littlechild, S. C., \& Owen, G. (1980). An Austrian model of the entrepreneurial market process. Journal of ECOnomic Theory, 23, 361-379.

Lucas, R. E. (1978). On the size distribution of firms. Bell Journal of Economics, 9, 508-523.

Lucas, R. E. (1988). On the mechanics of economic development. Journal of Monetary Economics, 22, 3-42.

McMullen, J. S., Bagby, D. R., \& Palich, L. E. (2008). Economic freedom and the motivation to engage in entrepreneurial action. Entrepreneurship Theory and Practice, 32, 875-895.

McMullen, J. S., \& Shepherd, D. (2006). Entrepreneurial action and the role of uncertainty in the theory of the entrepreneur. Academy of Management Review, 31, 132-152.

von Mises, L. (1949). Human action: A treatise on economics. London, UK: William Hodge.

Mokyr, J. (2009). The Enlightened Economy: An Economic History of Britain, 1700-1850. New Haven, CT: Yale University Press.

Munger, M. C. (2008). Economic choice, political decision, and the problem of limits. Public Choice, 137, 507-522. 
Nelson, R. R., \& Winter, S. G. (1982). An evolutionary theory of economic change. Cambridge, MA: Belknap Press.

North, D. N. (1990). Institutions, institutional change, and economic performance. Cambridge, UK: Cambridge University Press.

Nyström, K. (2008). The institutions of economic freedom and entrepreneurship: Evidence from panel data. Public Choice, 136, 269-282.

OECD. (2015). Entrepreneurship at a glance 2015. Paris: OECD Publishing.

Olson, M. (1982). The rise and decline of nations: Economic growth, stagflation, and social rigidities. New Haven, CT: Yale University Press.

Olson, M. (1996). Big bills left on the sidewalk: Why some nations are rich, and others poor. Journal of Economic Perspectives, 10, 3-24.

Ovaska, T., \& Sobel, R. S. (2005). Entrepreneurship in post-socialist economies. Journal of Private Enterprise, 21, 8-28.

Oxfeld, E. (1992). Individualism, holism, and the market mentality: Notes on the recollections of a Chinese entrepreneur. Cultural Anthropology, 7, 267-300.

Pacheco, D. F., York, J. G., Dean, T. J., \& Sarasvathy, S. (2010). The co-evolution of institutional entrepreneurship: A tale of two theories. Journal of Management, 36, 974-1010.

Parente, S. L., \& Prescott, E. C. (2005). A unified theory of the evolution of international income levels. In P. Aghion \& S. Durlauf (Eds.), Handbook of economic growth (pp. 1371-1416). Amsterdam: Elsevier.

Parker, S. C. (2005). The economics of entrepreneurship: What we know and what we don't. Foundations and Trends in Entrepreneurship, 1, 1-54.

Parker, S. C. (2011). Intrapreneurship or entrepreneurship? Journal of Business Venturing, 26, 19-34.

Rodrik, D., Subramanian, A., \& Trebbi, F. (2004). Institutions rule: The primacy of institutions over geography and integration in economic development. Journal of Economic Growth, 9, 131-165.

Romer, P. (1990). Endogenous technological change. Journal of Political Economy, 98, S71-S102.

Rumelt, R. (1987). The competitive challenge. Cambridge, UK: Ballinger.

Sala-i-Martin, X. (1997). I have just run two million regressions. American Economic Review, 87, 178-183.

Sanandaji, T., \& Leeson, P. T. (2014). Billionaires. Industrial and Corporate Change, 22, 313-337.

Schmitz, J. A. (1989). Imitation, entrepreneurship and long-run growth. Journal of Political Economy, 97, 721-739.
Schumpeter, J. A. (1911). Theorie der wirtschaftlichen entwicklung. Eine untersuchung ueber unternehmergewinn, kaptial, kredit, zins und den konjunkturzyklus. Berlin: Duncker und Humblot.

Schumpeter, J. A. (1939). Business cycles: A theoretical, historical and statistical analysis of the capitalist process. New York: McGraw-Hill.

Schumpeter, J. A. (1942). Capitalism, socialism and democracy. New York: Harper \& Row.

Scott, W. R. (1995). Institutions and organizations. London: Sage.

Shah, S. K., Smith, S. W., \& Reedy, E. J. (2012). Who are user entrepreneurs? Findings on innovation, founder characteristics, and firm characteristics. Kansas City, MO: Ewing Marion Kauffman Foundation.

Shane, S. (2000). A general theory of entrepreneurship: The individual-opportunity nexus. Cheltenham, UK: Edward Elgar.

Shane, S., \& Venkataraman, S. (2000). The promise of entrepreneurship as a field of research. Academy of Management Review, 25, 217-226.

Shepherd, D. (2011). Multilevel entrepreneurship research: Opportunities for studying entrepreneurial decision making. Journal of Management, 37, 412420.

Sobel, R. S., \& King, K. A. (2008). Does school choice increase the rate of youth entrepreneurship? Economics of Education Review, 27, 429-438.

Solow, R. M. (1956). A contribution to the theory of economic growth. Quarterly Journal of Economics, 70, 65-94.

Solow, R. M. (1957). Technical change and the aggregate production function. Review of Economics and Statistics, 39, 312-320.

van Stel, A. J. (2006). Empirical analysis of entrepreneurship and economic growth. New York: Springer.

Stigler, G. (1971). The theory of economic regulation. Bell Journal of Economics and Management Science, 2, 3-21.

Storey, D. J. (1994). Understanding the small business sector. London: Routledge.

Tajfel, H., \& Turner, J. C. (1979). An integrative theory of intergroup conflict. In W. G. Austin \& S. Worchel (Eds.), The social psychology of intergroup relations (pp. 33-47). Monterey, CA: Brooks/Cole.

Temple, J. (1999). The new growth evidence. Journal of Economic Literature, 37, 112-156.

Terjesen, S. A., Hessels, J., \& Li, D. (2016). Comparative international entrepreneurship: A review and research agenda. Journal of Management, 42, 299-344. 
Thornton, P. H. (1999). The sociology of entrepreneurship. Annual Review of Sociology, 25, 19-46.

Troilo, M. (2011). Legal institutions and high-growth aspiration entrepreneurship. Economic Systems, 35, 158-175.

Voigt, S. (2013). How (not) to measure institutions. Journal of Institutional Economics, 9, 1-26.

Wennekers, S., \& Thurik, A. R. (1999). Linking entrepreneurship and economic growth. Small Business Economics, 13, 27-55.

Wennekers, S., Uhlaner, L. A., \& Thurik, A. R. (2002). Entrepreneurship and its conditions: A macro perspective. International Journal of Entrepreneurship Education, 1, 25-64.

Wennekers, S., van Stel, A., Carree, M., \& Thurik, A. R. (2010). The relation between entrepreneurship and economic development: Is it U-shaped? Foundations and Trends in Entrepreneurship, 6, 167-237.

Westhead, P., \& Wright, M. (1998). Novice, portfolio, and serial founders: Are they different? Journal of Business Venturing, 13, 173-204.

Williamson, O. E. (1985). The economic institutions of capitalism: Firms, markets, and relational contracting. New York: Free Press.

Williamson, O. E. (1996). The mechanisms of governance. New York: Oxford University Press.

Yates, A. J. (2000). The knowledge problem, entrepreneurial discovery, and Austrian market process theory. Journal of Economic Theory, 91, 59-85.
Young, A. T., \& Wiseman, T. (2014). Religion: Productive or unproductive? Journal of Institutional Economics, 10, 21-45.

Zacharakis, A., McMullen, J., \& Shepherd, D. A. (2007). VC decision making across three countries: An institutional theory perspective. Journal of International Business Studies, 38, 691-708.

Zahra, S., \& Wright, M. (2011). Entrepreneurship's next act. Academy of Management Perspectives, 25, 67-83.

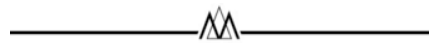

Christian Bjørnskov (chbj@econ.au.dk) is a professor at Aarhus University in Denmark. He is also an affiliated researcher with the Research Institute of Industrial Economics in Stockhom, Sweden. His research focuses on effects of institutional differences, including informal institutions, and their consequences for long-run economic and political development.

Nicolai J. Foss (njf.smg@cbs.dk) is a professor of organization theory at Bocconi University and holds professorial positions at the Warwick Business School and Norwegian School of Economics. His research has been published in the leading journals in management. He is a member of Academia Europaea. 


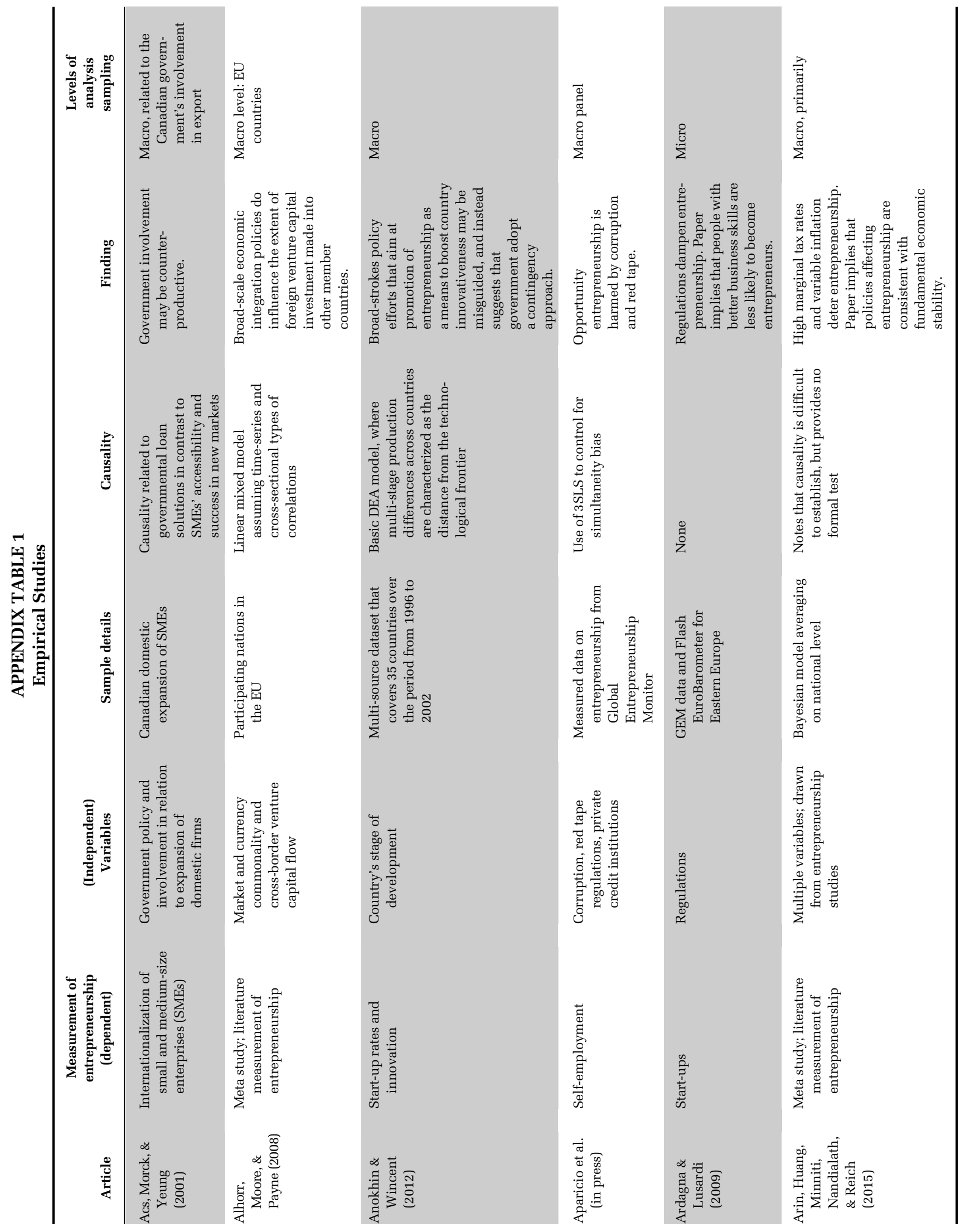




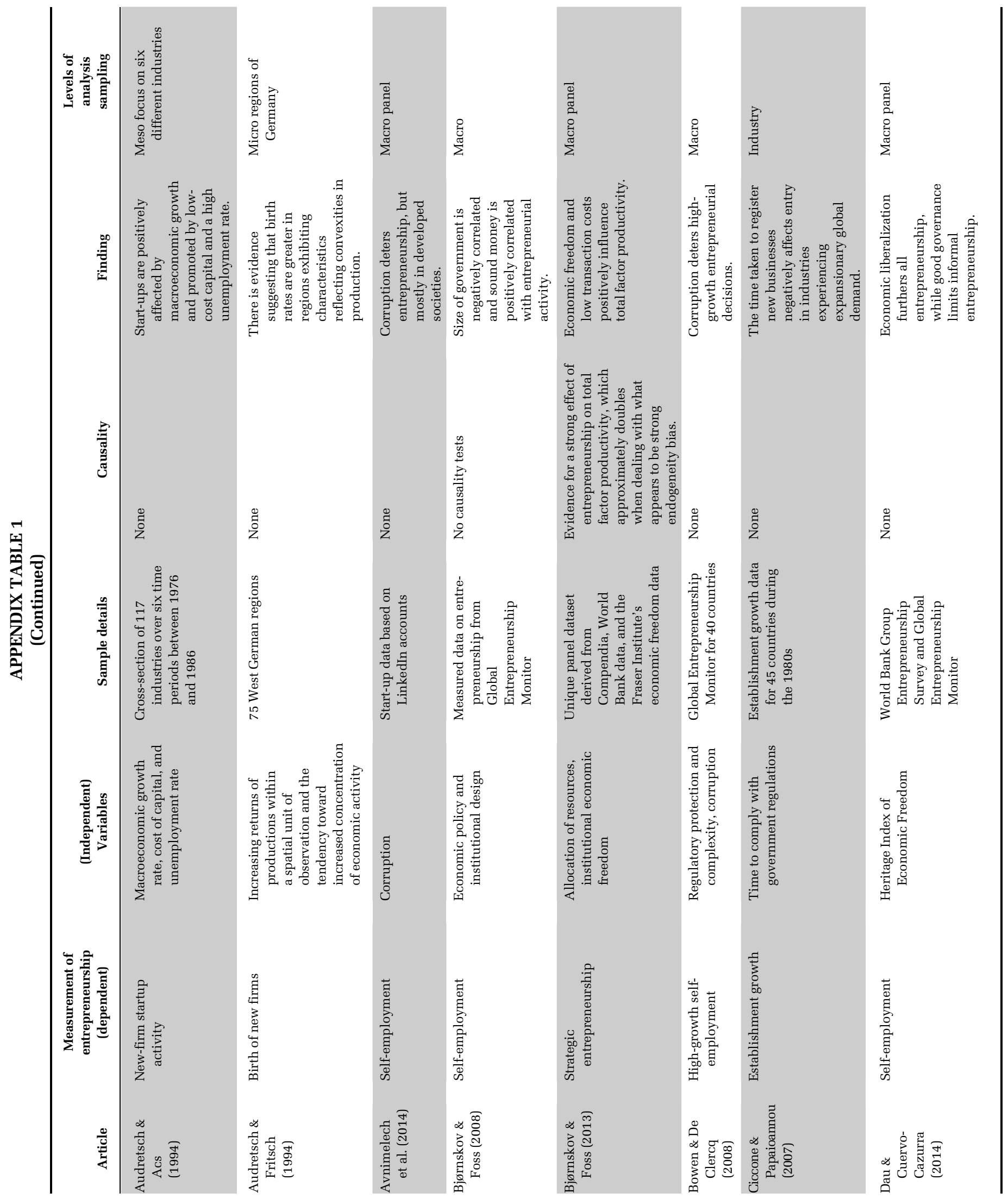




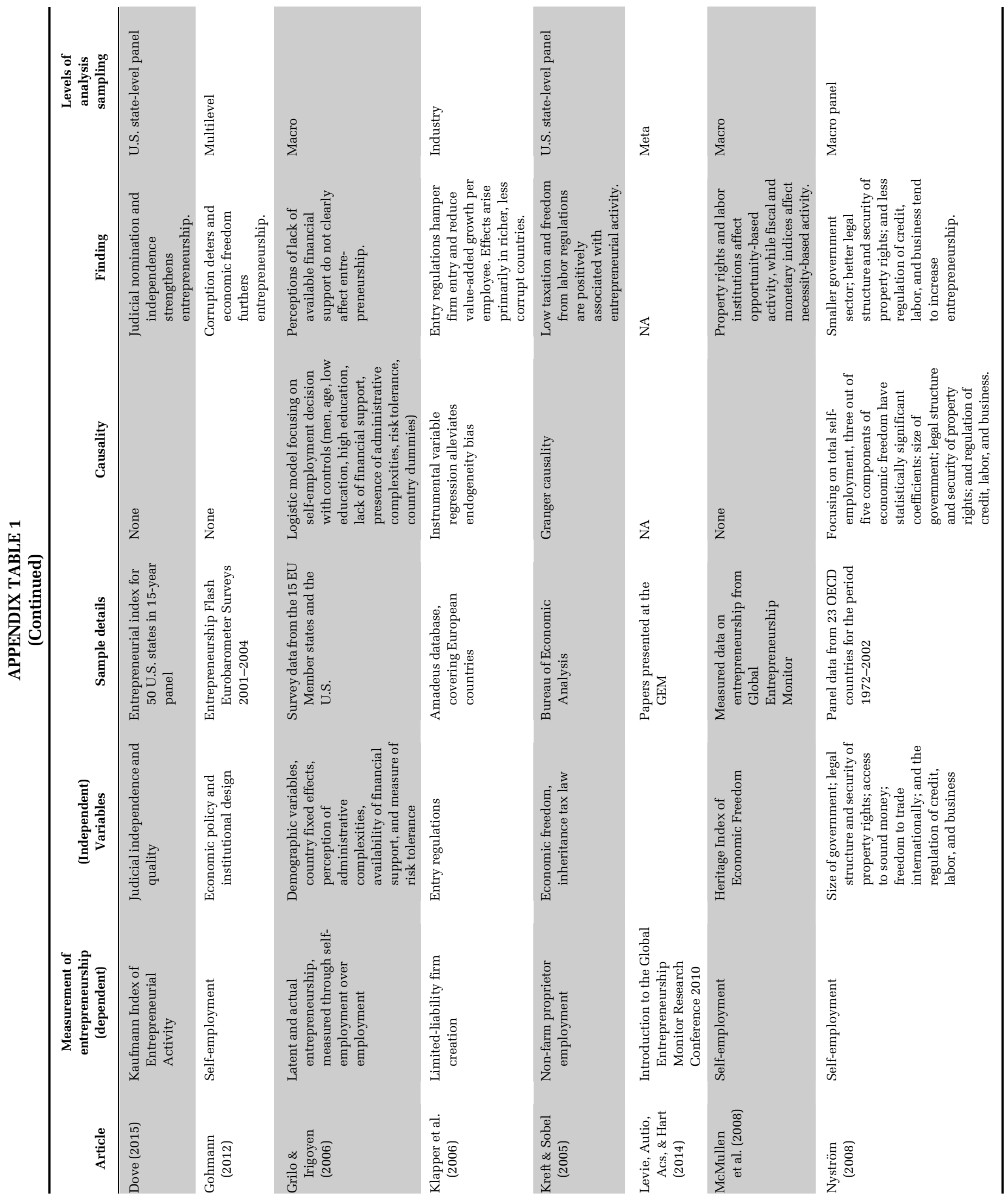




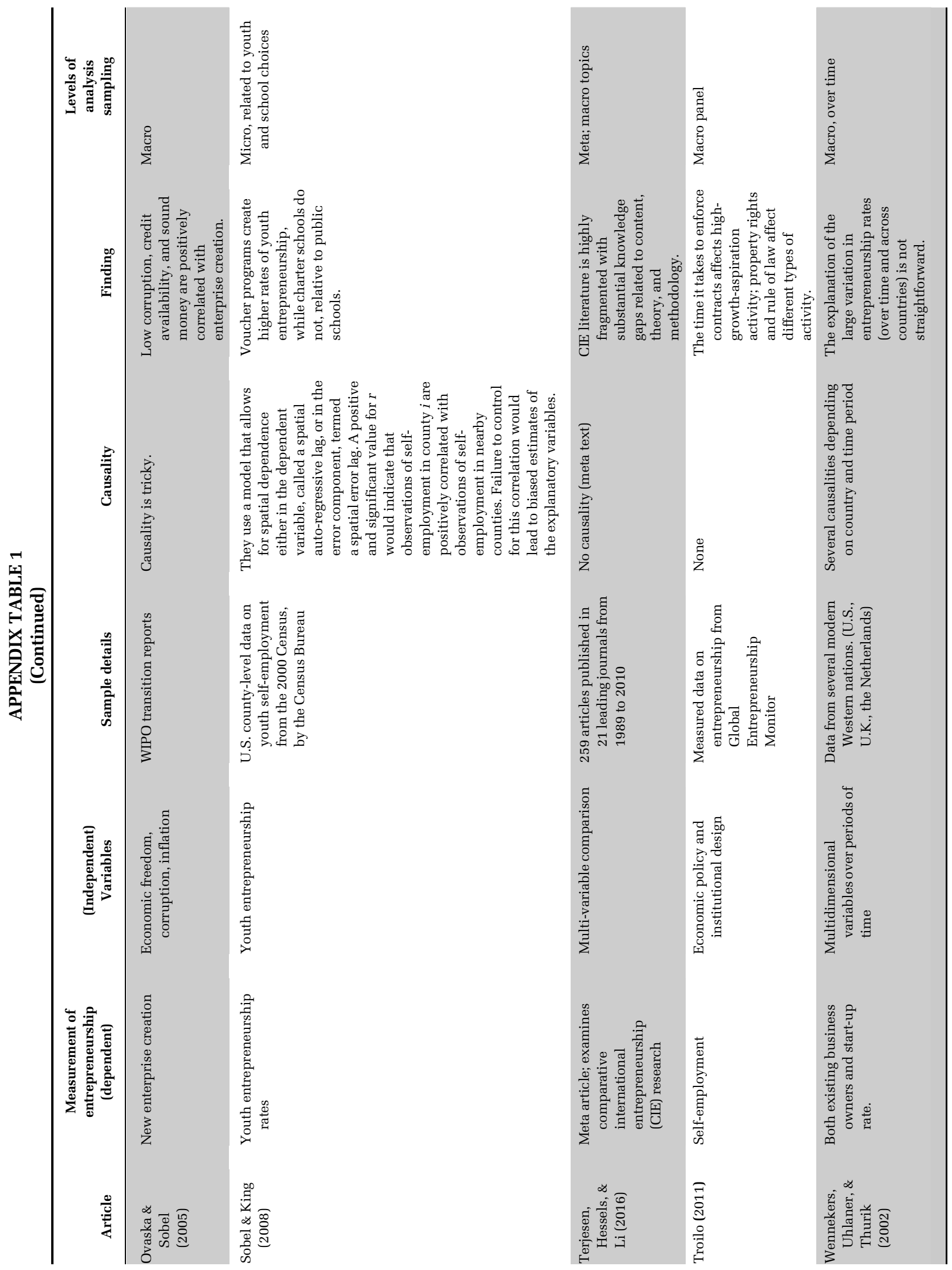




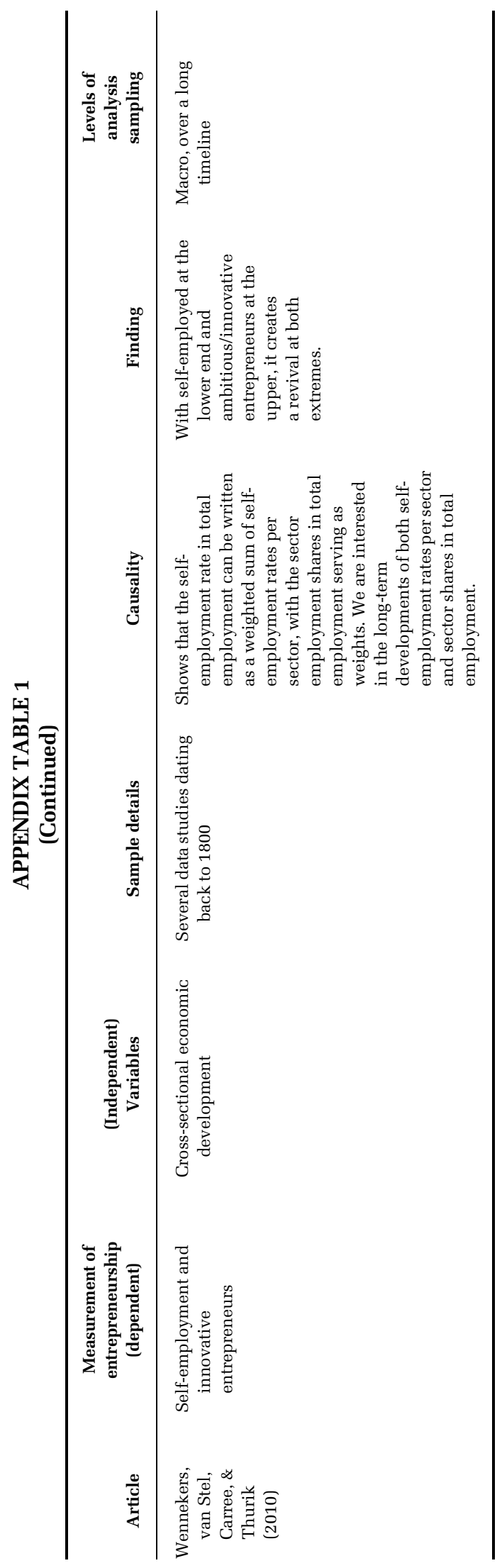


Copyright of Academy of Management Perspectives is the property of Academy of Management and its content may not be copied or emailed to multiple sites or posted to a listserv without the copyright holder's express written permission. However, users may print, download, or email articles for individual use. 